\title{
Article \\ Effect of Temperature and Nanoparticle Concentration on Free Convective Heat Transfer of Nanofluids
}

\author{
Janusz T. Cieśliński ${ }^{1, * \mathbb{D}}$, Slawomir Smolen ${ }^{2} \mathbb{D}$ and Dorota Sawicka ${ }^{2}$ \\ 1 Faculty of Mechanical Engineering and Ship Technology, Institute of Energy, Gdansk University of \\ Technology, Narutowicza 11/12, 80233 Gdańsk, Poland \\ 2 Faculty of Nature and Engineering, J.R. Mayer-Institute for Energy Engineering, City University of Applied \\ Sciences Bremen, Neustadtswall 30, 28199 Bremen, Germany; slawomir.smolen@fh-bremen.de (S.S.); \\ dorota.czerwonka@gmail.com (D.S.) \\ * Correspondence: jcieslin@pg.edu.pl
}

\section{check for} updates

Citation: Cieśliński, J.T.; Smolen, S.; Sawicka, D. Effect of Temperature and Nanoparticle Concentration on Free Convective Heat Transfer of Nanofluids. Energies 2021, 14, 3566. https://doi.org/10.3390/en14123566

Received: 20 May 2021

Accepted: 14 June 2021

Published: 15 June 2021

Publisher's Note: MDPI stays neutral with regard to jurisdictional claims in published maps and institutional affiliations.

Copyright: (c) 2021 by the authors. Licensee MDPI, Basel, Switzerland This article is an open access article distributed under the terms and conditions of the Creative Commons Attribution (CC BY) license (https:// creativecommons.org/licenses/by/ $4.0 /)$.
Abstract: A theoretical analysis of the influence of temperature and nanoparticle concentration on free convection heat transfer from a horizontal tube immersed in an unbounded nanofluid was presented. The Nusselt $(\mathrm{Nu})$ number and heat transfer coefficient were parameters of the intensity of the convective heat transfer. For free convection, the Nu number was a function of the Rayleigh (Ra) number and Prandtl (Pr) number. The Rayleigh (Ra) number and Prandtl (Pr) number were functions of the thermophysical properties of nanofluids. The thermophysical properties of nanofluids varied with temperature and nanoparticle concentration. Therefore, an analysis was conducted to evaluate the effects on the performance of nanofluids due to variations of thermal conductivity, viscosity, thermal expansion, density, and specific heat, which are functions of nanoparticle concentration and temperature. Water- and ethylene glycol (EG)-based nanofluids with dispersed alumina $\left(\mathrm{Al}_{2} \mathrm{O}_{3}\right)$ nanoparticles at mass concentrations of $0.01 \%, 0.1 \%$, and $1 \%$ were considered. Calculated $\mathrm{Nu}$ numbers and heat transfer coefficients were compared with experimental values taken from the published literature.

Keywords: nanofluids; thermophysical properties; free convective heat transfer; horizontal cylinder

\section{Introduction}

A nanofluid is a suspension consisting of a base liquid and metallic or non-metallic nanoparticles with sizes significantly smaller than $100 \mathrm{~nm}$. Despite the small amount of nanoparticles from a few ppm to several percent of volume or mass concentration, the nanofluids exhibit completely different thermophysical properties compared to the base fluids. As a result, distinct heat transfer enhancement can be observed. Of particular interest is single phase convective heat transfer due to potential applications in many cooling systems [1-4].

Contrary to forced convection heat transfer, e.g., [5-7], little attention has been paid to study free convection of nanofluids. Khanafer et al. [8] numerically stated that the application of nanofluid during free convection in a 2D enclosure substantially enhances heat transfer. Putra et al. [9] experimentally studied free convection of water- $\mathrm{Al}_{2} \mathrm{O}_{3}$ and water-CuO nanofluids inside a horizontal cylinder with heated and cooled end covers. A systematic decrease in heat transfer with the increasing volume concentration of nanoparticles was noted. Wen and Ding [10] experimentally found out that the addition of nanoparticles to base fluid leads to an increase in the thermal conductivity and viscosity of nanofluids. However, a decrease in the Nu number and Ra number was observed, and it was difficult to establish relative importance of the thermal conductivity and viscosity of nanofluids. Polidori et al. [11] studied theoretically free convection over a vertical plate. They pointed out the role of viscosity in free convection heat transfer of nanofluids. Ho et al. [12] investigated experimentally free convection in vertical enclosure. They established substantial 
enhancement of heat transfer even for nanofluids with low nanoparticle concentration. Li and Peterson [13] studied experimentally free convection inside a cylindrical gap heated from below. The gradual deterioration of heat transfer coefficient was observed with the increase in the volume fraction of the nanoparticles in the nanofluids. Mahrood et al. [14] conducted experiments with non-Newtonian fluids. Experiments were carried out in vertical cylinders. The dependence of nanoparticle concentration and aspect ratio enhancement or deterioration of heat transfer was observed. Cieśliński and Krygier [15] recorded substantial deterioration of heat transfer during free convection of nanofluids from horizontal porous coated tubes. Garbadeen et al. [16] studied experimentally free convection of water-MWCNT nanofluids in a square enclosure with differentially heated side walls. Substantial enhancement of heat transfer was observed for optimum nanoparticle volume concentration of $0.1 \%$. Rahimi et al. [17] investigated experimentally and numerically free convection heat transfer of water-DMCNT nanofluids in a cuboid enclosure. For nanoparticle concentrations higher than $0.01 \%$, a decrease in the $\mathrm{Nu}$ number and average heat transfer coefficient was noted. Minea and Lorenzini [18] found out numerically that during free convection of water- $\mathrm{ZnO}$ nanofluids in a rectangular enclosure, the $\mathrm{Nu}$ number decreases and the entropy generation increases with the increase in Ra number. Reddy and Chamkha [19] studied numerically the influence of buoyancy and Brownian motion on heat transfer from a horizontal cylinder placed in a porous medium filled with nanofluid. Guestal et al. [20] investigated numerically the free convection of water-Cu and water- $\mathrm{TiO}_{2}$ nanofluids in a partially heated horizontal cylindrical enclosure. The study showed improvement of heat transfer as the Ra number increased. Moreover, the $\mathrm{Nu}$ number increased with the increasing nanoparticle concentration. Sawicka et al. [21] established numerically that the increase in nanoparticle concentration leads to a decrease in $\mathrm{Nu}$ number, Ra number, and an increase in the heat transfer coefficient during free convection of nanofluids from a horizontal cylinder.

Existing correlations for the free convection heat transfer of nanofluids [9-11] relate the Nusselt $(\mathrm{Nu})$ number only to Ra number: $\mathrm{Nu}=\mathrm{f}(\mathrm{Ra})$. As it was demonstrated in [22], the Nu number is not only a function of Ra, but the Pr number as well: $\mathrm{Nu}=\mathrm{f}(\mathrm{Ra}, \operatorname{Pr})$. Therefore, for nanofluids, a more accurate correlation equation would be: $\mathrm{Nu}=\mathrm{f}(\mathrm{Ra}, \mathrm{Pr}$, $\varphi)$. It is well known that thermophysical properties of nanofluids are dependent upon nanoparticle concentration and temperature [23-25]. However, the change of specific heat and density of nanofluids with nanoparticle concentration and temperature is modest [26-29]. The thermal conductivity of nanofluids increases moderately with an increase in temperature and nanoparticle concentration [30-32]. The viscosity of nanofluids, in turn, decreases substantially with an increase in temperature and increases with an increase in nanoparticle concentration [33-35]. Therefore, it is very difficult to evaluate the relative importance of viscosity and thermal conductivity. However, as the Nu number increases with an increase in Prandtl number, it is interesting to question the impact of temperature and nanoparticle concentration on Pr number variation. A key parameter in free convection heat transfer is the thermal expansion coefficient, and it was experimentally established [12] that the thermal expansion coefficient for water- $\mathrm{Al}_{2} \mathrm{O}_{3}$ nanofluids increases substantially with an increase in temperature, and the change with nanoparticle concentration is modest. Khanafer and Vafai [23] demonstrated that literature correlations have not properly estimated the thermal expansion coefficient of water- $\mathrm{Al}_{2} \mathrm{O}_{3}$ nanofluids when compared to the experimental data of Ho et al. [12]. Therefore, using the experimental data of Ho et al. [12], they proposed a new correlation as a function of nanoparticle concentration and temperature jointly.

In this paper, according to the best author's knowledge, for the first time, a theoretical analysis was carried out on water- $\mathrm{Al}_{2} \mathrm{O}_{3}$ and $\mathrm{EG}-\mathrm{Al}_{2} \mathrm{O}_{3}$ nanofluids to determine the influence of temperature and nanoparticle concentration on thermophysical properties of nanofluids, and as a consequence, on Pr number variation, Ra number variation, $\mathrm{Nu}$ number variation, and heat transfer coefficient variation. Because the Ra number, $\mathrm{Nu}$ number, and consequently, the heat transfer coefficient, are functions of the characteristic 
length, it was necessary to define geometry of the thermal system. In the present study, free convection heat transfer from a horizontal tube immersed in an unbounded nanofluid was analyzed. Alumina nanoparticles $\left(\mathrm{Al}_{2} \mathrm{O}_{3}\right)$ were considered at the concentration of $0.01 \%$, $0.1 \%$, and $1 \%$ by weight within the temperature range $20-40^{\circ} \mathrm{C}$. The range of the considered parameters was selected the same as in experimental study presented in [36]; therefore, a comparison of the calculated values of Nu numbers and heat transfer coefficients with experimental results was conducted.

\section{Materials and Methods}

\subsection{Correlations for Free Convection Heat Transfer from Horizontal Cylinders}

For free convection heat transfer of the base fluids, the Nusselt number was calculated from the recognized Churchill and Chu correlation equation [37].

$$
\mathrm{Nu}=\left(0.6+\frac{0.387 \cdot \mathrm{Ra}^{\frac{1}{6}}}{\left[1+\left(\frac{0.559}{\mathrm{Pr}}\right)^{\frac{9}{16}}\right]^{\frac{8}{27}}}\right)^{2}
$$

which is valid for all Ra numbers and Pr numbers. The correlation served for prediction of the referenced heat transfer coefficient.

Contrary to forced convection heat transfer, e.g., [38-41], few correlations exist for free convection heat transfer, and these are mostly devoted to heat transfer in enclosures [42].

Recently, Habibi et al. [43] numerically developed correlation equations for laminar free convection heat transfer of water $-\mathrm{Al}_{2} \mathrm{O}_{3}$ nanofluids from an isolated, horizontal cylinder as follows:

$$
\begin{aligned}
& \mathrm{Nu}=\left(0.4667+0.1213 \varphi_{\mathrm{v}}^{0.6817}\right) \mathrm{Ra}^{1 / 4} \\
& \mathrm{Nu}=\left(0.4667-1.0761 \varphi_{\mathrm{v}}^{1.35014}\right) \mathrm{Ra}^{1 / 4}
\end{aligned}
$$

which is valid for $10 \leq \mathrm{Ra} \leq 10^{6}$ and $\left(0 \%<\varphi_{\mathrm{V}}<20 \%\right)$.

Sawicka et al. [36] proposed an experimentally developed correlation equation for free convection heat transfer of water- $\mathrm{Al}_{2} \mathrm{O}_{3}, \mathrm{EG}-\mathrm{Al}_{2} \mathrm{O}_{3}$, and water/EG- $\mathrm{Al}_{2} \mathrm{O}_{3}$ nanofluids from an isolated, horizontal cylinder in the form:

$$
\mathrm{Nu}=0.63 \operatorname{Ra}^{0.23} \cdot \operatorname{Pr}^{0.053} \cdot\left(1-\varphi_{\mathrm{m}}\right)^{2.64}
$$

which is valid for $3 \times 10^{4} \leq \mathrm{Ra} \leq 1.3 \times 10^{6}$ and $0.01 \%<\varphi_{\mathrm{m}}<1 \%$.

\subsection{Analyzed Nanofluids}

In this theoretical study, the same base fluids and nanoparticles were considered as used in [36], where distilled, deionized water and EG served as base fluids, and $\mathrm{Al}_{2} \mathrm{O}_{3}$ were used as nanoparticles. Alumina nanoparticles were examined at the concentration of $0.01 \%$, $0.1 \%$, and $1 \%$ by weight. The mean diameter of nanoparticle was equal to $d_{p}=47 \mathrm{~nm}$.

The properties of alumina $\left(\mathrm{Al}_{2} \mathrm{O}_{3}\right)$ nanoparticles are shown in Table 1 .

Table 1. Properties of $\mathrm{Al}_{2} \mathrm{O}_{3}$ nanoparticles.

\begin{tabular}{cccc}
\hline $\begin{array}{c}\text { Density [44] } \\
\rho_{\mathrm{p}}\left[\mathrm{kg} / \mathrm{m}^{3}\right]\end{array}$ & $\begin{array}{c}\text { Specific Heat [44] } \\
\mathrm{c}_{\mathrm{pp}}[\mathrm{J} /(\mathbf{k g ~ K})]\end{array}$ & $\begin{array}{c}\text { Thermal } \\
\text { Conductivity [45] } \\
\mathbf{k}_{\mathrm{p}}[\mathrm{W} /(\mathbf{m K})\end{array}$ & $\begin{array}{c}\text { Thermal Expansion } \\
\text { Coefficient [12] } \\
\boldsymbol{\beta}_{\mathrm{p}}[\mathbf{1} / \mathrm{K}]\end{array}$ \\
\hline 3600 & 765 & 35 & $8.46 \times 10^{-6}$ \\
\hline
\end{tabular}




\subsection{Correlations for Thermophysical Properties of Nanofluids}

A large number of correlations devoted to calculating viscosity of nanofluids is published in the literature, e.g., [46,47]. Corcione [48] proposed following correlation equation for viscosity of the water- $\mathrm{Al}_{2} \mathrm{O}_{3}$ and $\mathrm{EG}-\mathrm{Al}_{2} \mathrm{O}_{3}$ nanofluids:

$$
\mu_{n f}=\mu_{b f}\left(\frac{1}{1-34.87\left(\frac{d_{p}}{d_{f}}\right)^{-0.3} \varphi_{v}^{1.03}}\right)
$$

where $d_{f}$ is the equivalent diameter of a base fluid molecule:

$$
d_{f}=0.1\left(\frac{6 M}{N \rho_{f o}}\right)^{1 / 3}
$$

in which $M$ is the molecular weight of the base fluid $\left(M_{H_{2} O}=18 \mathrm{~kg} / \mathrm{kmol}\right.$ and $M_{E G}=$ $62.07 \mathrm{~kg} / \mathrm{kmol}, N=6.02214076 \times 10^{26} \mathrm{kmol}^{-1}$ (Avogadro number), and $\rho_{f o}$ is the density of the base fluid calculated at temperature $\mathrm{T}_{\mathrm{O}}=293 \mathrm{~K}$.

Viscosity of the pure water reads [49]:

$$
\mu_{b f}=1.435 \cdot 10^{-5} \cdot e^{\frac{1226.8}{T}}
$$

and viscosity of the pure EG reads [49]:

$$
\mu_{b f}=1.6 \cdot 10^{-7} \cdot e^{\frac{3440}{T}}
$$

Figure 1 shows the influence of nanoparticle concentration on the viscosity of the tested nanofluids against temperature calculated from Equation (5) for water- and EG-based nanofluids.

As seen in Figure 1, viscosity of the tested nanofluids decreases sharply with temperature increase and slightly increases with nanoparticle mass concentration increase. The maximum increase in viscosity of $\mathrm{EG}-\mathrm{Al}_{2} \mathrm{O}_{3}$ nanofluid with $1 \%$ nanoparticle concentration compared to pure EG is $1.1 \%$.

Similarly to viscosity, several correlations devoted to calculating thermal conductivity of nanofluids have been published in literature, e.g., [30,50]. For thermal conductivity of water- $\mathrm{Al}_{2} \mathrm{O}_{3}$ nanofluids, Sawicka et al. [49] proposed the following correlation equation:

$$
k_{n f}=k_{b f}\left(1+0.1046 \varphi_{m}^{0.2388}\left(100 / d_{p}\right)^{3.14 \cdot 10^{-3}}\right)
$$

where thermal conductivity of pure water is:

$$
k_{b f}=1.974 \cdot 10^{-3} \cdot T
$$

For EG- $\mathrm{Al}_{2} \mathrm{O}_{3}$ nanofluids, the experimentally developed correlation is of the form:

$$
k_{n f}=k_{b f}\left(1+0.0193\left(\frac{k_{p}}{k_{b f}}\right)^{6.15 \cdot 10^{-3}} \varphi_{m}^{0.0738}\left(100 / d_{p}\right)^{9.76 \cdot 10^{-5}}\right)
$$

where thermal conductivity of pure EG is:

$$
k_{b f}=8.49 \cdot 10^{-4} \cdot T
$$

The developed correlations are valid for $0.01 \% \leq \varphi_{m} \leq 1 \%$ and $293 \mathrm{~K} \leq \mathrm{T} \leq 313 \mathrm{~K}$. 


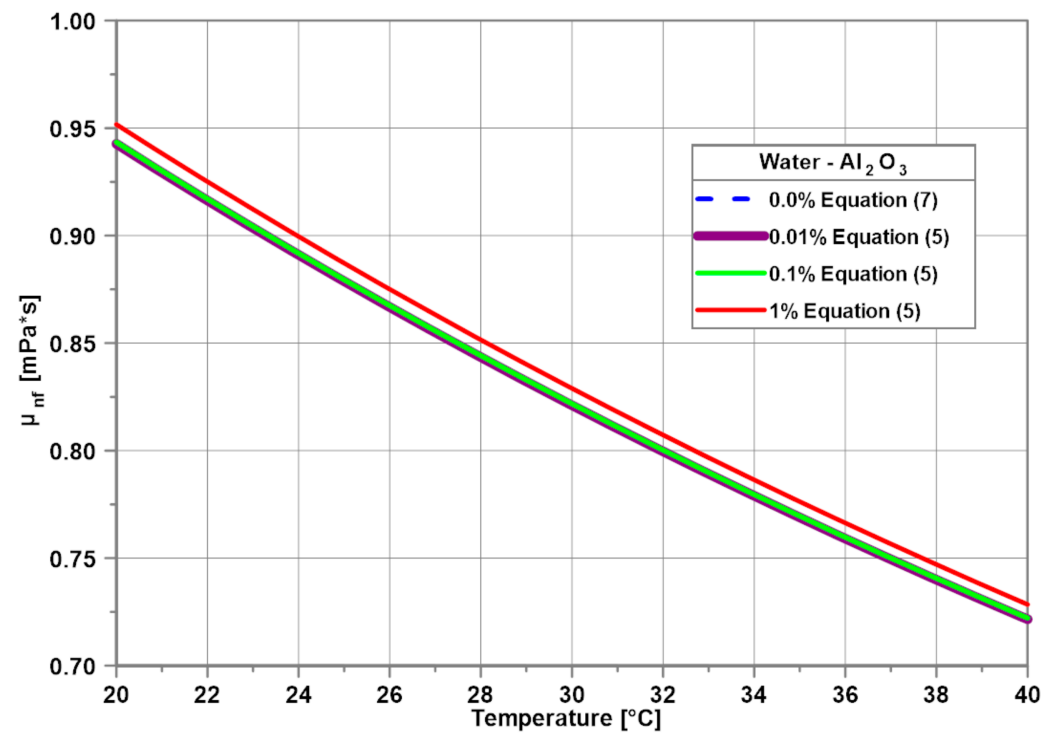

(a)

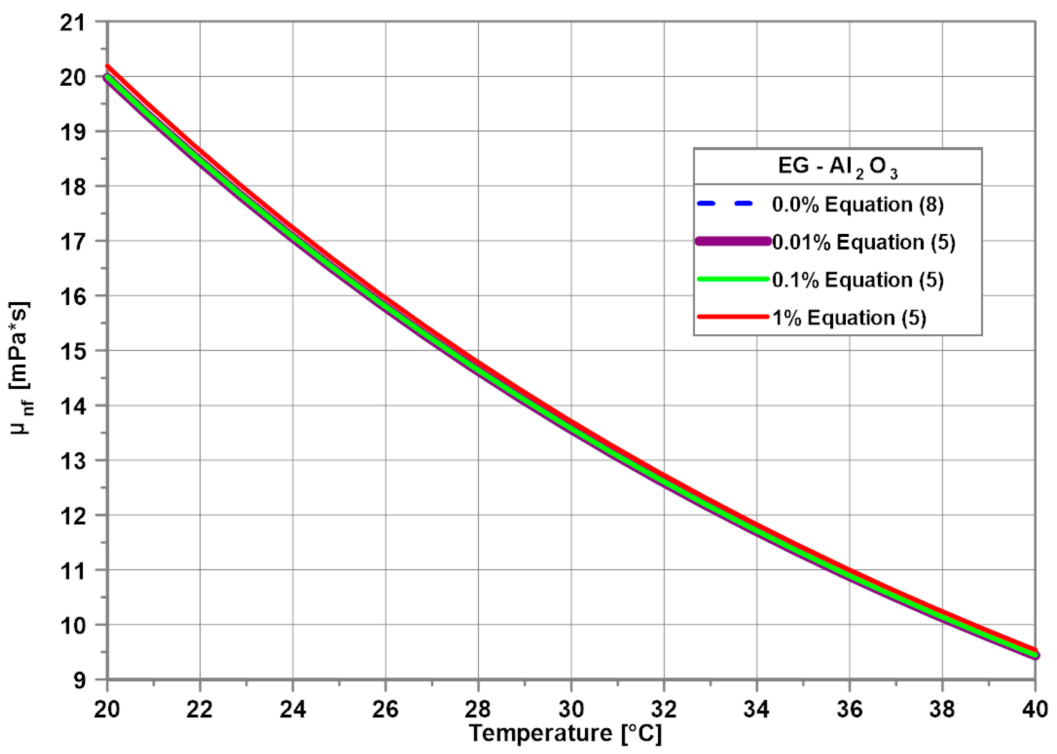

(b)

Figure 1. Viscosity of the water-based (a) and EG-based (b) nanofluids.

Figure 2 shows the influence of nanoparticle concentration on the thermal conductivity of the tested nanofluids against temperature calculated from Equations (9) and (11) for water- and EG-based nanofluids, respectively.

As seen in Figure 2, the thermal conductivity of the tested nanofluids increases moderately with the temperature increase and for given temperature increases with nanoparticle concentration increase. Interesting is that the increase in thermal conductivity is more distinct for water- $\mathrm{Al}_{2} \mathrm{O}_{3}$ and the increase amounts $2.4 \%$ within the whole temperature range. 


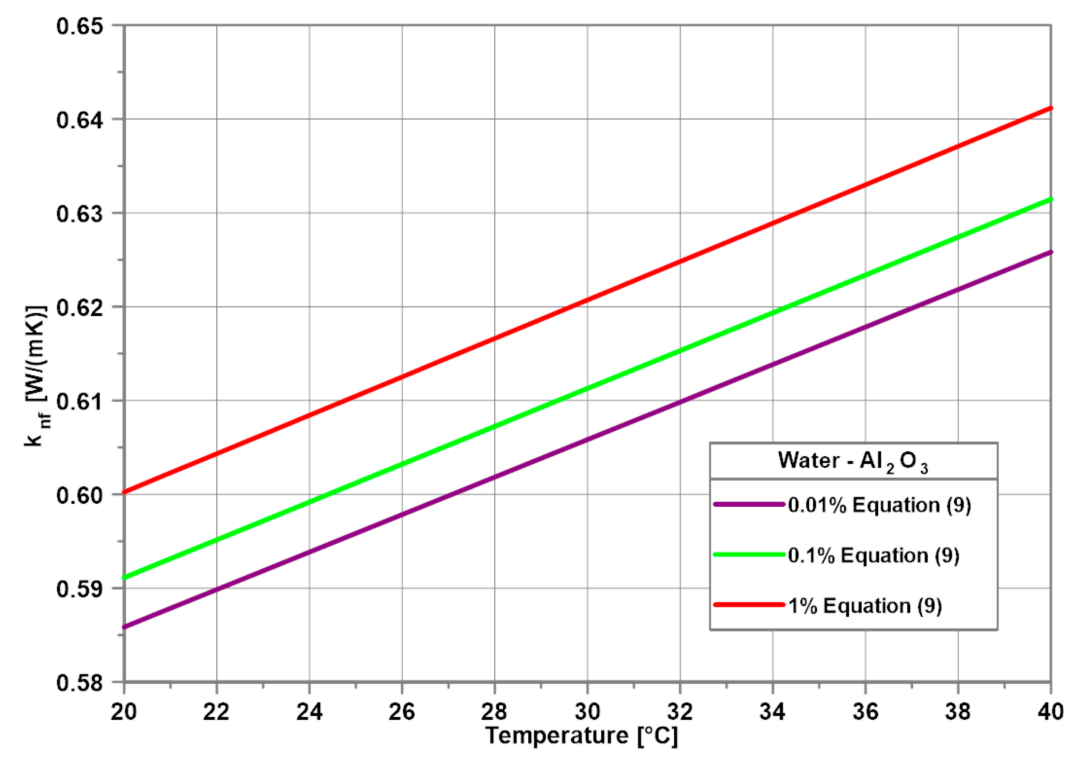

(a)

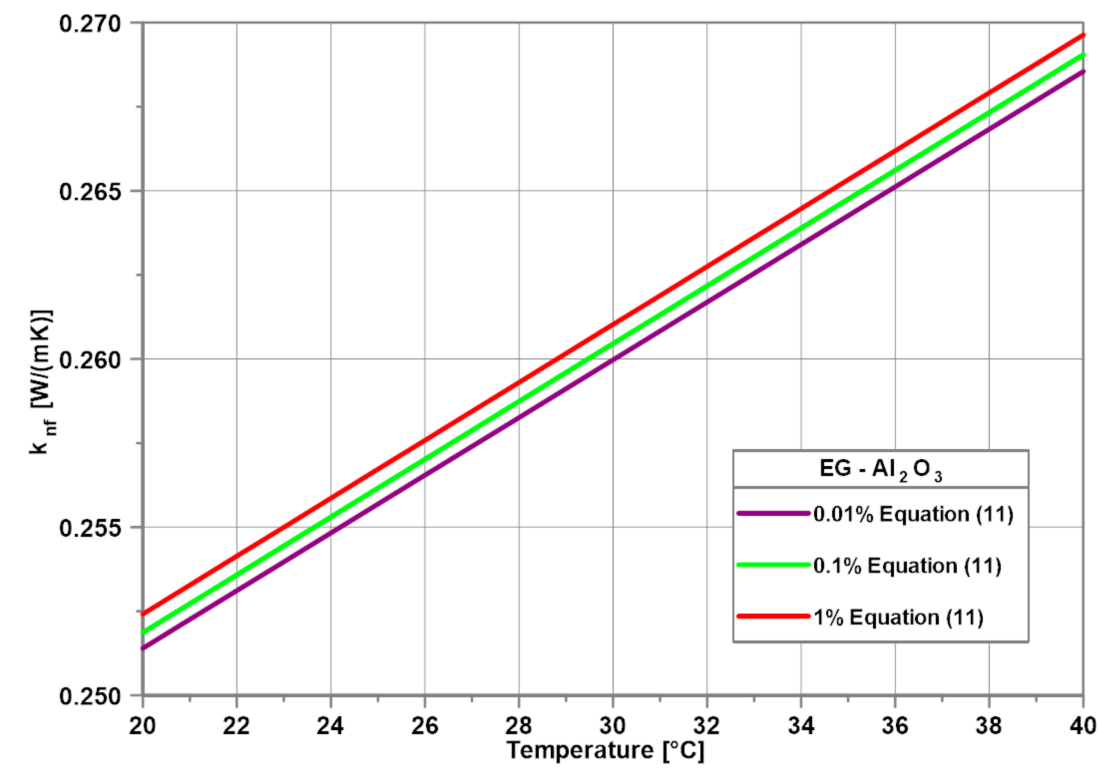

(b)

Figure 2. Thermal conductivity of the water-based (a) and EG-based (b) nanofluids.

The commonly accepted equation proposed in [38] was used to estimate the density of the tested nanofluids:

$$
\rho_{n f}=\varphi_{v} \rho_{p}+\left(1-\varphi_{v}\right) \rho_{b f}
$$

where density of pure water and pure EG is given by the Equations (14) and (15), respectively:

$$
\begin{gathered}
\rho_{b f}=1107.6-0.3708 \cdot T \\
\rho_{b f}=1331.2-0.732 \cdot T
\end{gathered}
$$

Equations (14) and (15) are based on the data provided by the ASHRAE Handbook [51]. Figure 3 illustrates the influence of the nanoparticle concentration on the density of the tested nanofluids as a function of temperature calculated from Equations (13)-(15). 


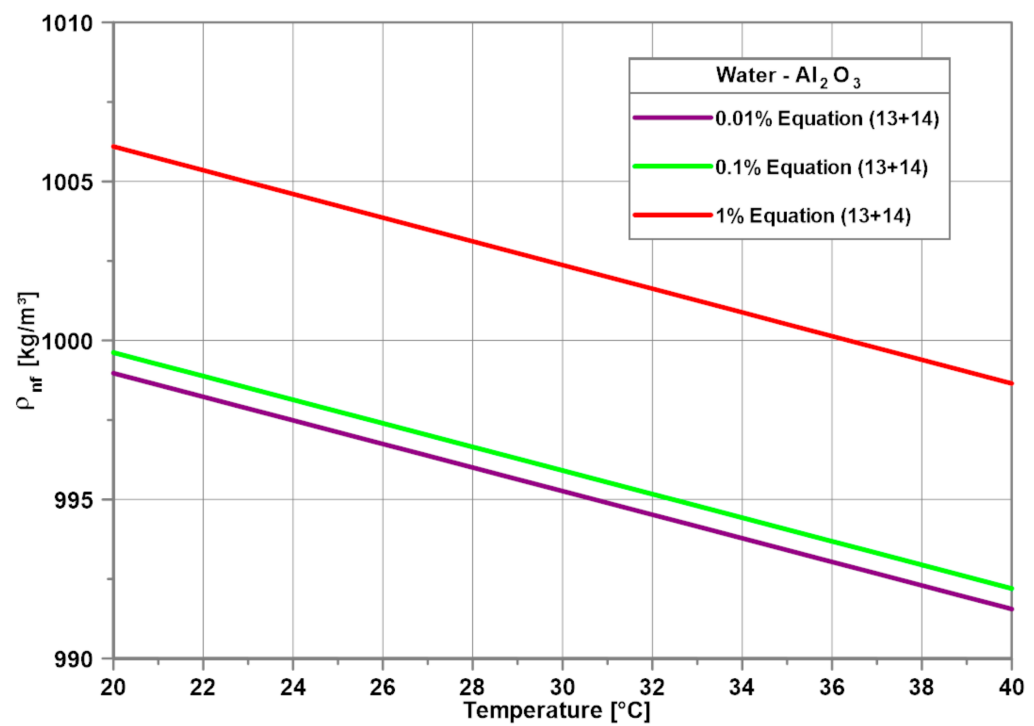

(a)

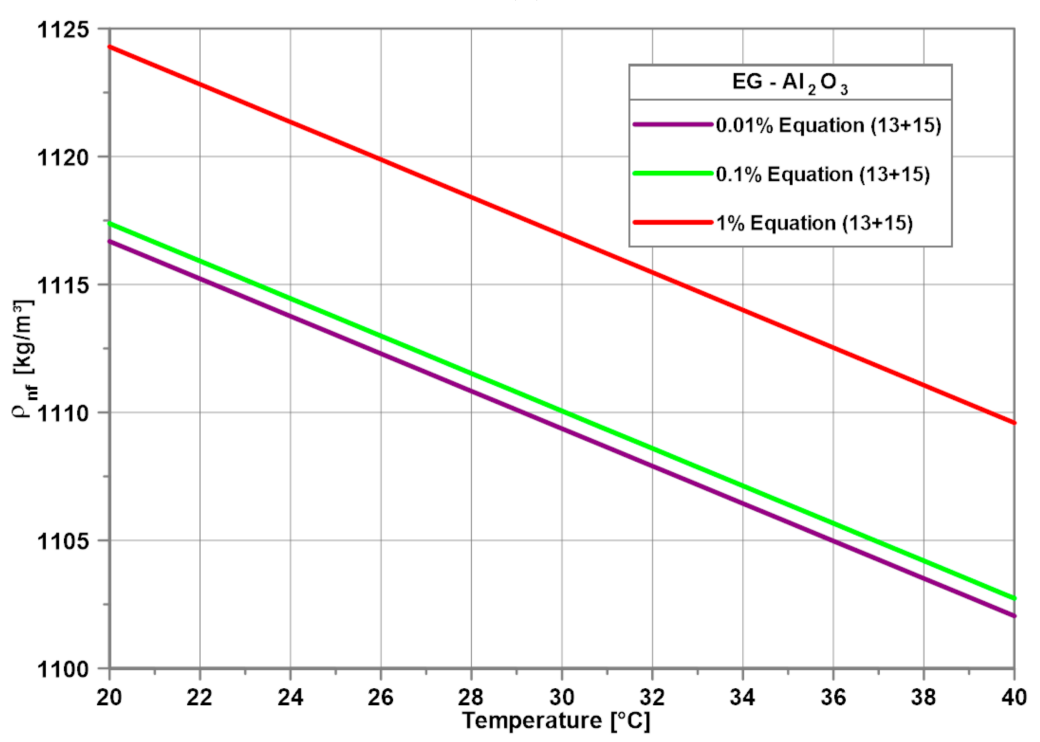

(b)

Figure 3. Density of the water-based (a) and EG-based (b) nanofluids.

As seen in Figure 3, the density of the analyzed nanofluids decreases with the temperature increase and increases with the nanoparticle concentration increase because the density of the nanoparticle material (Table 1) is higher than the density of pure water or pure EG.

In order to calculate the specific heat of the tested nanofluids, the correlation equation proposed in [44] was used:

$$
c_{p n f}=\frac{\left(1-\varphi_{v}\right) \rho_{b f} c_{p b f}+\varphi_{v} \rho_{p} c_{p p}}{\rho_{b f}}
$$

where the specific heat of pure water and pure EG is given by the Equations (17) and (18), respectively:

$$
\begin{gathered}
c_{p b f}=5603-9.2129 \cdot T+0.0149 \cdot T^{2} \\
c_{p b f}=1062.3+4.507 \cdot T
\end{gathered}
$$


Equations (17) and (18) are based on the data provided by the ASHRAE Handbook [51]. Figure 4 illustrates the influence of nanoparticle concentration on the specific heat of the tested nanofluids as a function of temperature calculated from Equations (16)-(18).

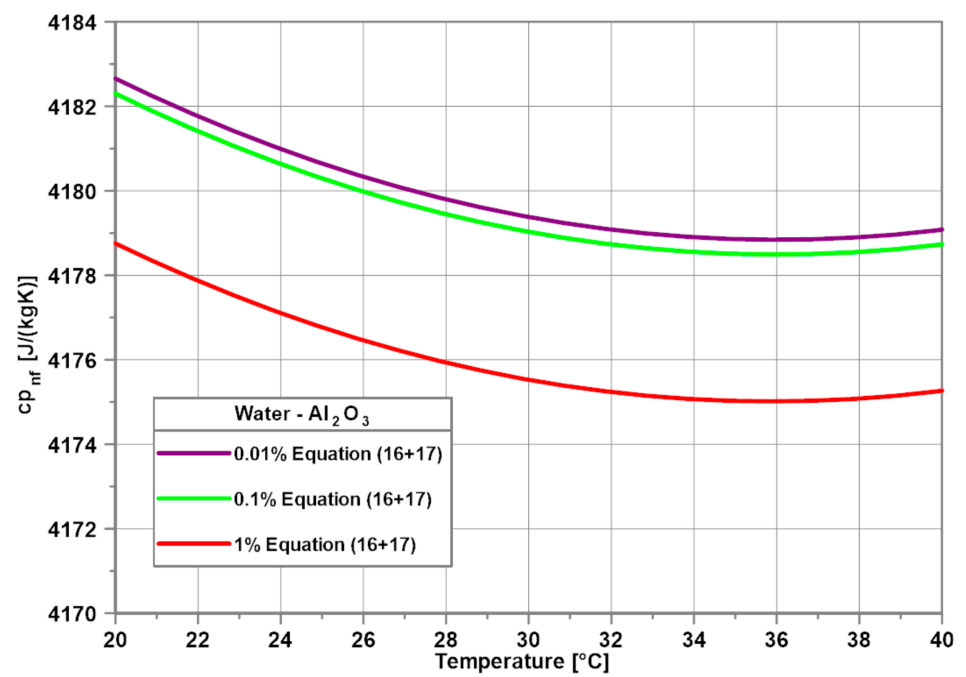

(a)

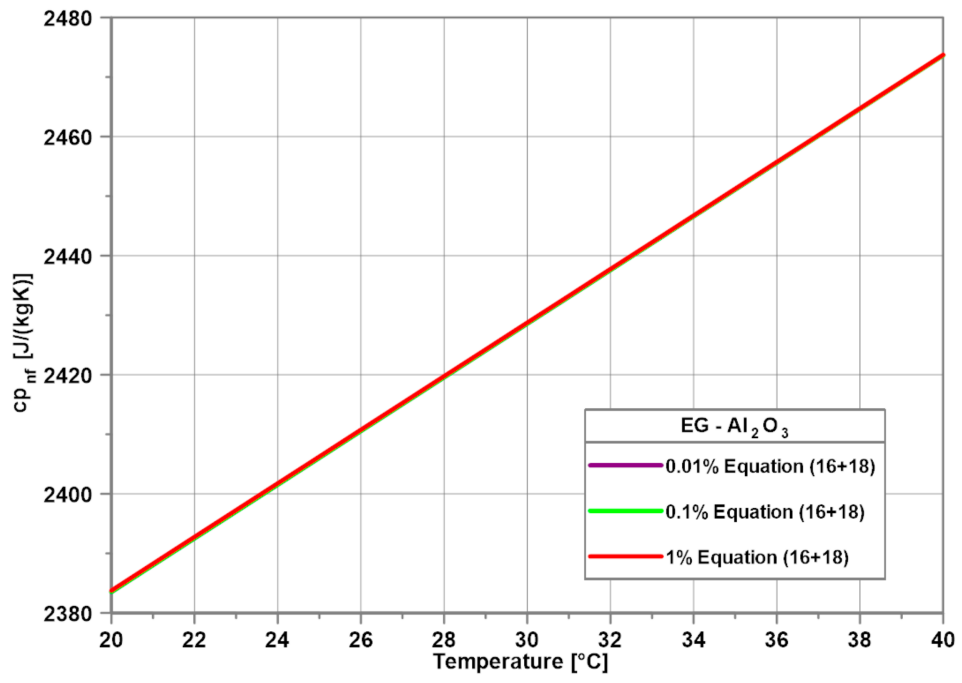

(b)

Figure 4. Specific heat of the water-based (a) and EG-based (b) nanofluids.

As seen in Figure 4, the specific heat of water-based nanofluids decreases with the temperature increase and for given temperature decreases with the nanoparticle concentration increase because the specific heat of the nanoparticle material (Table 1) was lower than the specific heat of pure water. It is worthy to note the nonmonotonic course of the specific heat for water-based nanofluids against temperature (Figure 4a) that results from data for pure water. Contrary to water-based nanofluids, the specific heat of EG-based nanofluids increased with temperature increase and was independent on the nanoparticle mass concentration tested.

Thermal expansion coefficient of water- $\mathrm{Al}_{2} \mathrm{O}_{3}$ nanofluids was determined from the correlation proposed in [23]:

$$
\beta_{n f}=\left(-0.479 \varphi_{v}+9.3158 \cdot 10^{-3} t-\frac{4.7211}{t^{2}}\right) \cdot 10^{-3}
$$

which is valid for $0 \leq \varphi_{v} \leq 0.04$ and $10{ }^{\circ} \mathrm{C} \leq t \leq 40^{\circ} \mathrm{C}$. 
For pure water thermal expansion coefficient was calculated from Equation (19) assuming $\varphi_{v}=0$, namely:

$$
\beta_{b f}=\left(9.3158 \cdot 10^{-3} t-\frac{4.7211}{t^{2}}\right) \cdot 10^{-3}
$$

Thermal expansion coefficient of EG- $\mathrm{Al}_{2} \mathrm{O}_{3}$ nanofluids was determined from the correlation proposed in [52,53]:

$$
\beta_{n f}=\left(1-\varphi_{v}\right)_{b f}+\varphi_{v p}
$$

where the thermal expansion coefficient of pure EG is $\beta_{b f}=0.000651 / \mathrm{K}$ [54]. Figure 5 illustrates the influence of the nanoparticle concentration on the thermal expansion coefficient of the tested nanofluids as a function of temperature calculated from Equations (19) and (21) for water- $\mathrm{Al}_{2} \mathrm{O}_{3}$ and $\mathrm{EG}-\mathrm{Al}_{2} \mathrm{O}_{3}$ nanofluids, respectively.

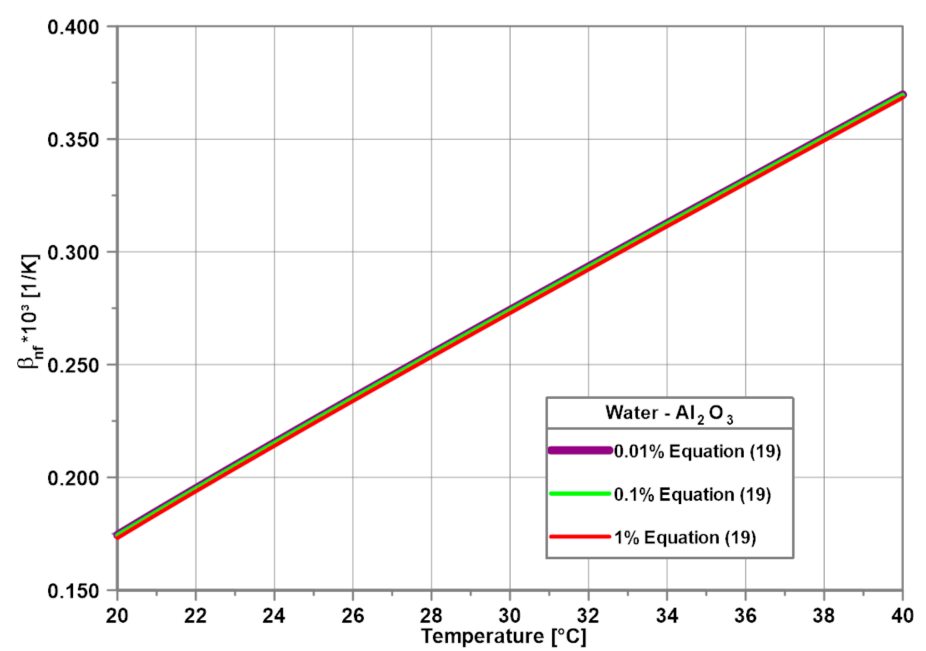

(a)

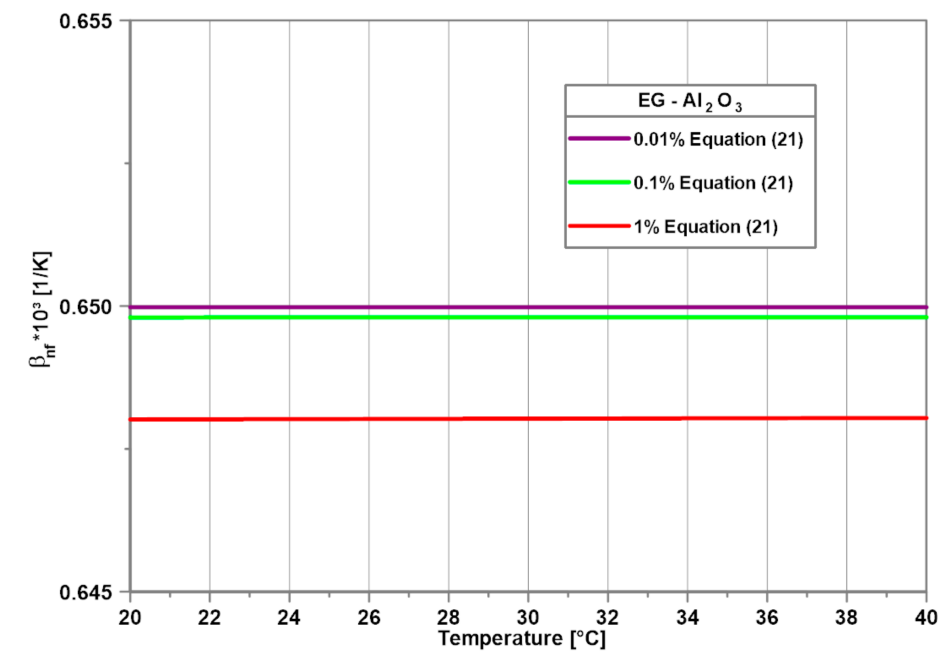

(b)

Figure 5. Thermal expansion coefficient of water-based (a) and EG-based (b) nanofluids.

As seen in Figure 5a, the thermal expansion coefficient for water-based nanofluids increases almost linearly with temperature and is independent on the tested mass nanoparticle concentration. For EG-based nanofluids, the thermal expansion coefficient did not depend on the temperature and slightly decreased for the maximum nanoparticle concentration tested. 


\section{Results}

\subsection{Variaton of Prandtl Number}

Figure 6 shows a comparison of the Pr numbers of the tested water- $\mathrm{Al}_{2} \mathrm{O}_{3}$ (Figure 6a) and EG- $\mathrm{Al}_{2} \mathrm{O}_{3}$ (Figure $6 \mathrm{~b}$ ) nanofluids as a function of temperature. For the tested nanofluids, the Pr number decreased with an increase in temperature, predominantly due to the decrease in viscosity (Figure 1). For water- $\mathrm{Al}_{2} \mathrm{O}_{3}$ nanofluids-independently of mass nanoparticle concentration-the Pr number decreased by about $29 \%$ with the temperature increase from 20 to $40{ }^{\circ} \mathrm{C}$. For EG- $\mathrm{Al}_{2} \mathrm{O}_{3}$ nanofluids-independently of mass nanoparticle concentration-the Pr number decreased by about $55 \%$ with the temperature increase from 20 to $40{ }^{\circ} \mathrm{C}$. The decrease in the Pr number with temperature was more distinct for EG- $\mathrm{Al}_{2} \mathrm{O}_{3}$ nanofluids than in the case of water- $\mathrm{Al}_{2} \mathrm{O}_{3}$ nanofluids, because of the more significant decrease in viscosity with temperature-Figure 1.

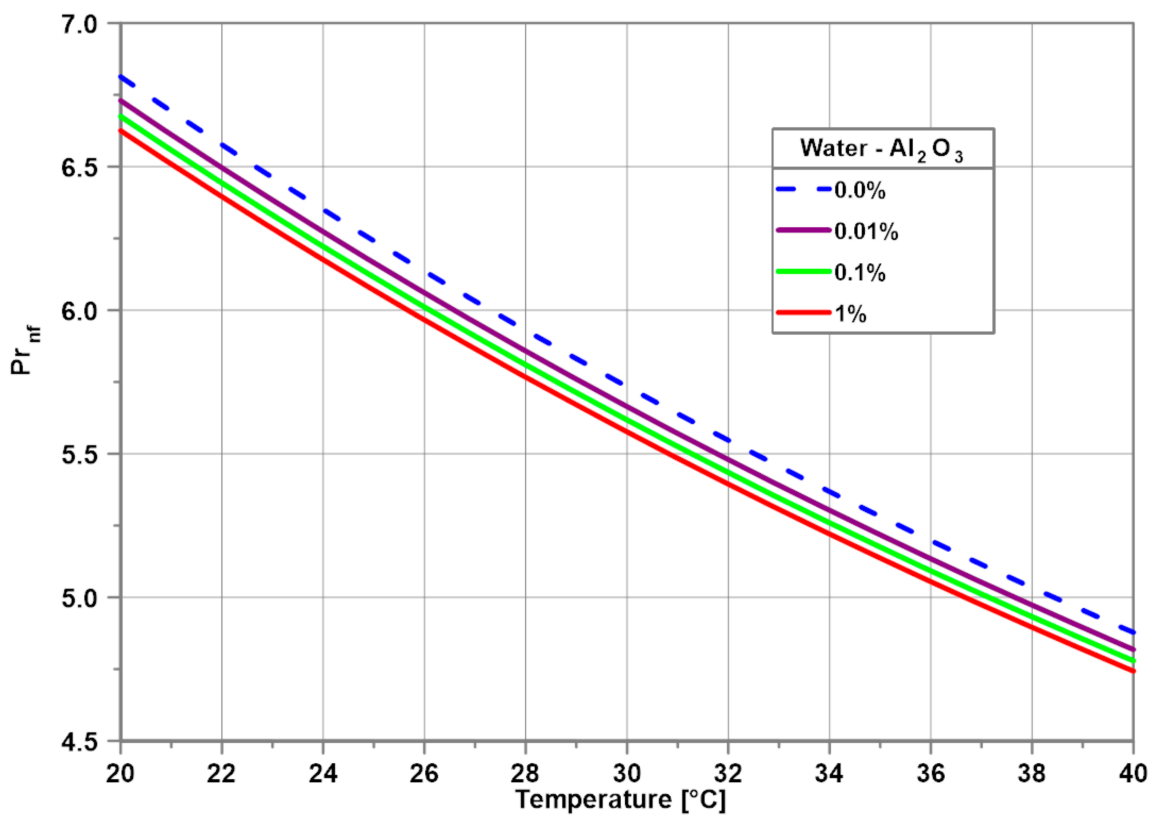

(a)

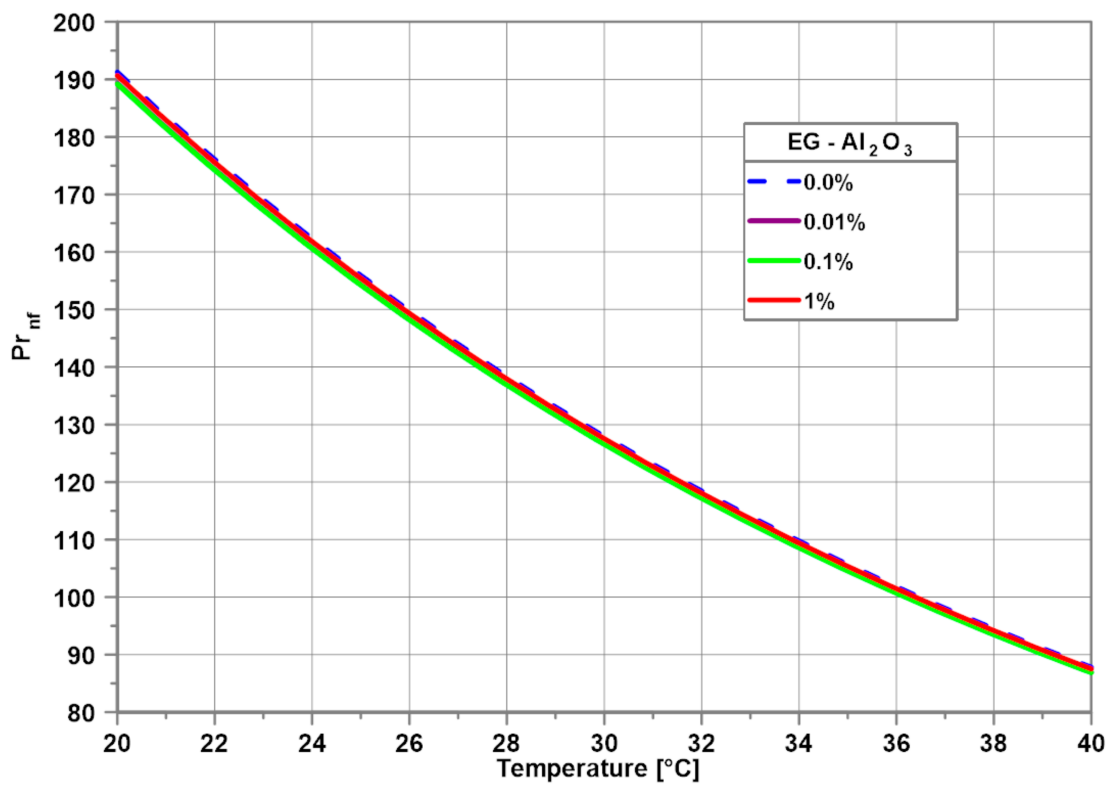

(b)

Figure 6. Prandtl number water-based (a) and EG-based (b) nanofluids. 
Figure 7 illustrates the influence of nanoparticle mass concentration on the Pr number of the tested nanofluids at two temperatures, namely 20 and $40{ }^{\circ} \mathrm{C}$. As seen in Figure $7 \mathrm{a}$, the Pr number for water- $\mathrm{Al}_{2} \mathrm{O}_{3}$ decreased slightly with nanoparticle concentration increase. The decrease in the Prandtl number did not depend on temperature and for the nanoparticle mass concentration of $1 \%$ equalled $2.7 \%$. For EG- $\mathrm{Al}_{2} \mathrm{O}_{3}$ nanofluids, the influence of nanoparticle mass concentration on the Pr number was negligible.

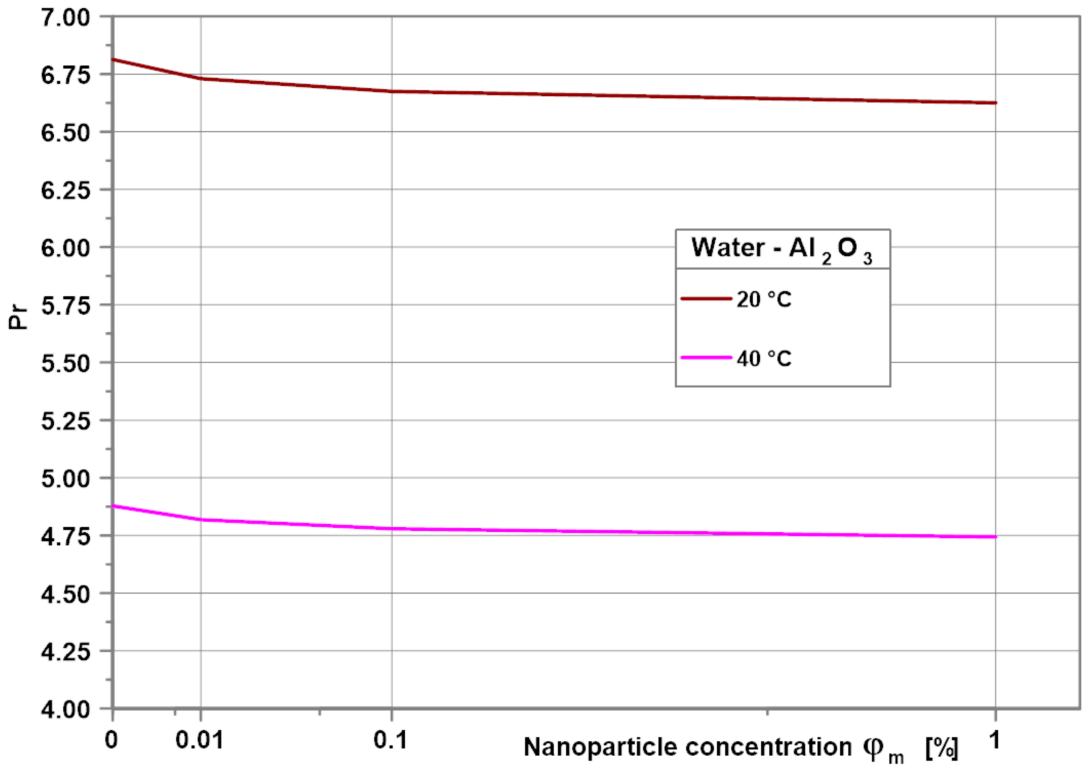

(a)

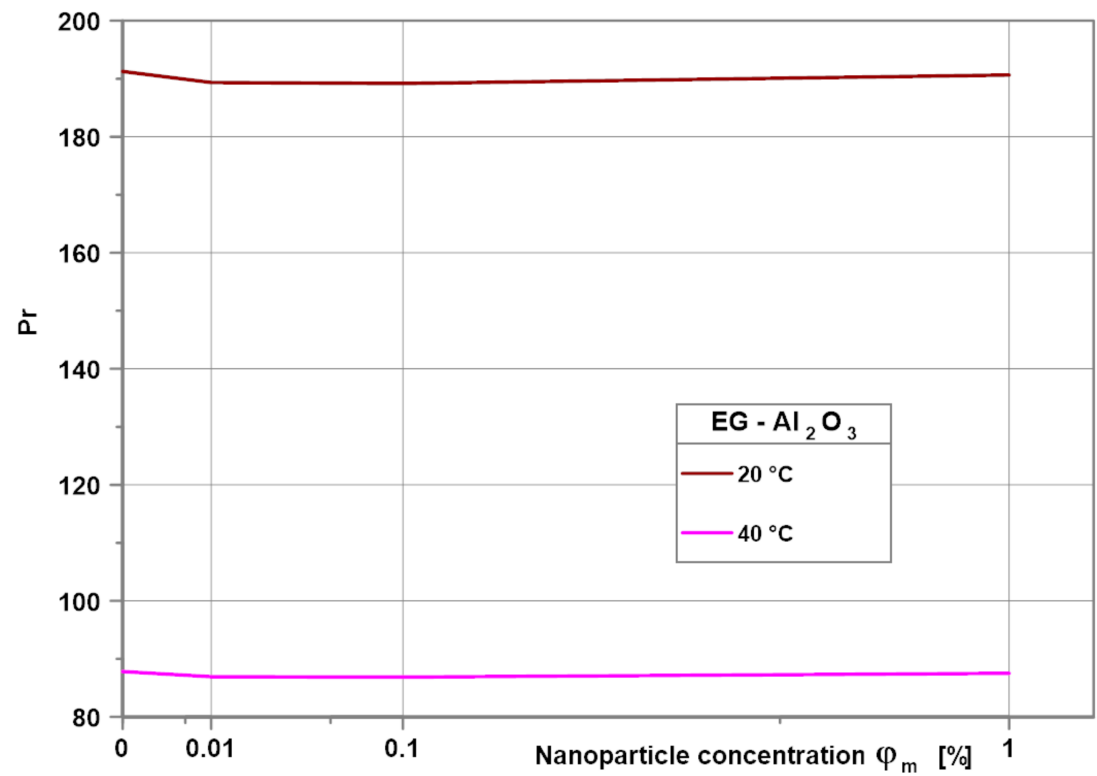

(b)

Figure 7. Variation of Pr number with nanoparticle mass concentration for water-based (a) and EG-based (b) nanofluids.

\subsection{Variaton of Rayleigh Number}

Figure 8 illustrates the change of Ra number versus temperature for the tested nanofluids. In this case the temperature difference and the diameter of the horizontal cylinder are held constant at the values taken from the experiment presented in [36] $-\Delta \mathrm{T}=10 \mathrm{~K}$, $\mathrm{D}=10 \mathrm{~mm}$. The Ra number was a function of all discussed thermophysical properties; 
however, the most significant parameters were viscosity and thermal expansion coefficient in the case of water based nanofluids (Figure 5a). The Ra number definitively increased with temperature increase, which also resulted in the increase in the $\mathrm{Nu}$ number. For water- $\mathrm{Al}_{2} \mathrm{O}_{3}$ nanofluids and the mass nanoparticle concentration of $0.01 \%$, the Ra number increased by about $162 \%$ with the temperature increase from 20 to $40{ }^{\circ} \mathrm{C}$. For EG- $\mathrm{Al}_{2} \mathrm{O}_{3}$ nanofluids the Ra number increased-independently of mass nanoparticle concentrationby about $106 \%$ with the temperature increase from 20 to $40{ }^{\circ} \mathrm{C}$. The increase in the Ra number with temperature was more distinct for water- $\mathrm{Al}_{2} \mathrm{O}_{3}$ nanofluids than in the case of EG- $\mathrm{Al}_{2} \mathrm{O}_{3}$ nanofluids, because of the more significant increase in the thermal expansion coefficient with temperature (Figure 5).

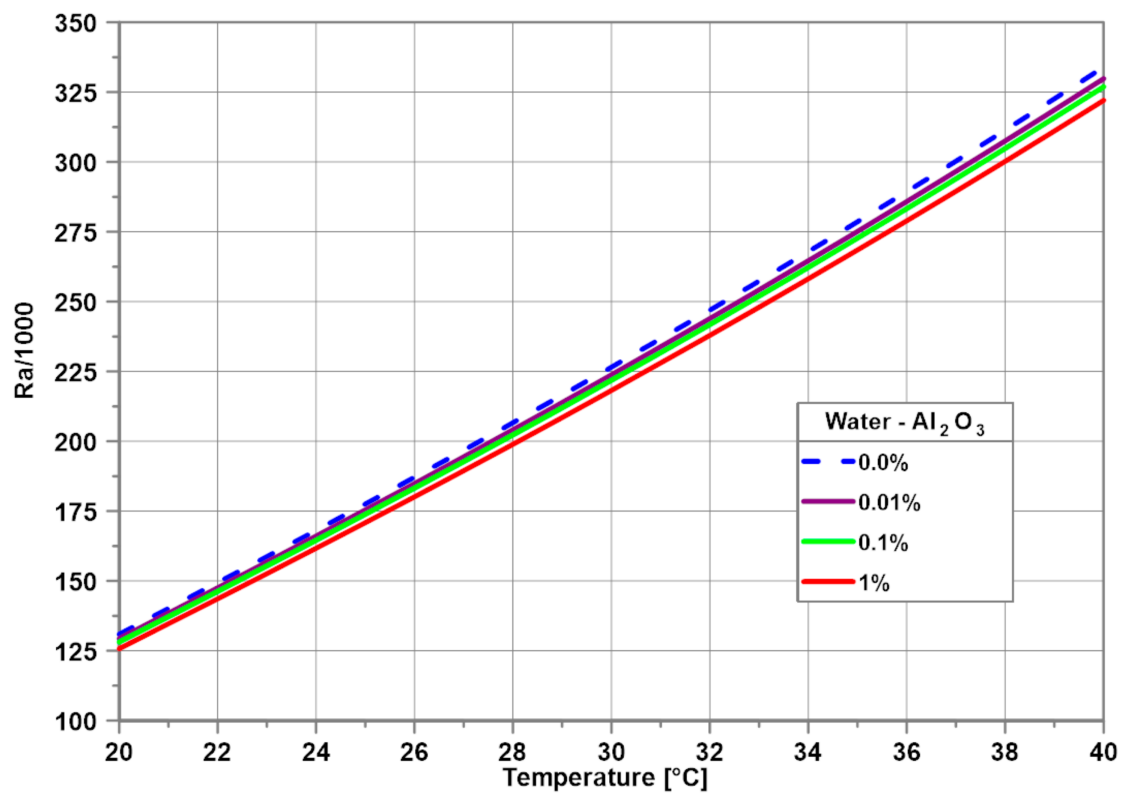

(a)

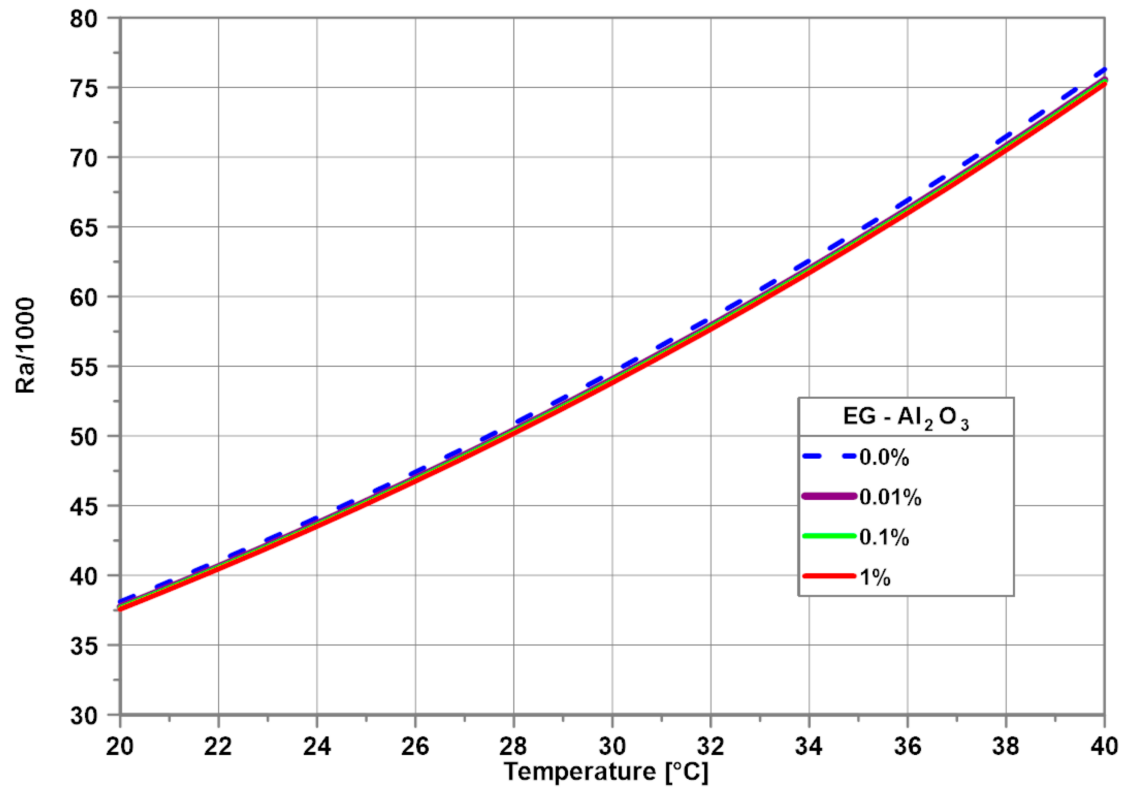

(b)

Figure 8. Variation of Rayleigh number with temperature for water-based (a) and EG-based (b) nanofluids. 
Figure 9 shows the change in the Ra number against mass nanoparticle concentration for selected temperatures. It was observed that an increase in the nanoparticle concentration resulted in a gradual decrease in the Ra number for all tested temperatures. An increase in the nanoparticle concentration increased the viscosity (Figure 1) and thermal conductivity of nanofluids (Figure 2). However, the rate of increase in viscosity was higher than the increase in the thermal conductivity. Therefore, the final result was a decrease in Ra number due to an increase in nanoparticle concentration. The maximum decrease in the Ra number for water- $\mathrm{Al}_{2} \mathrm{O}_{3}$ and EG- $\mathrm{Al}_{2} \mathrm{O}_{3}$ nanofluids, at the temperature of $40{ }^{\circ} \mathrm{C}$, equalled $3.6 \%$ and $1.4 \%$, respectively.

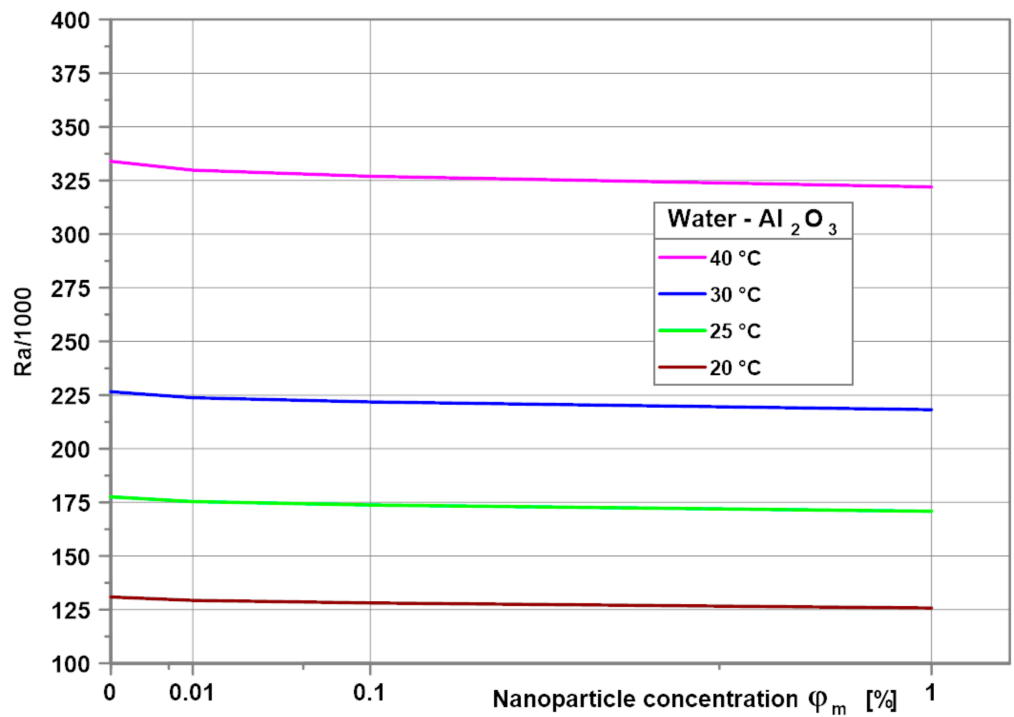

(a)

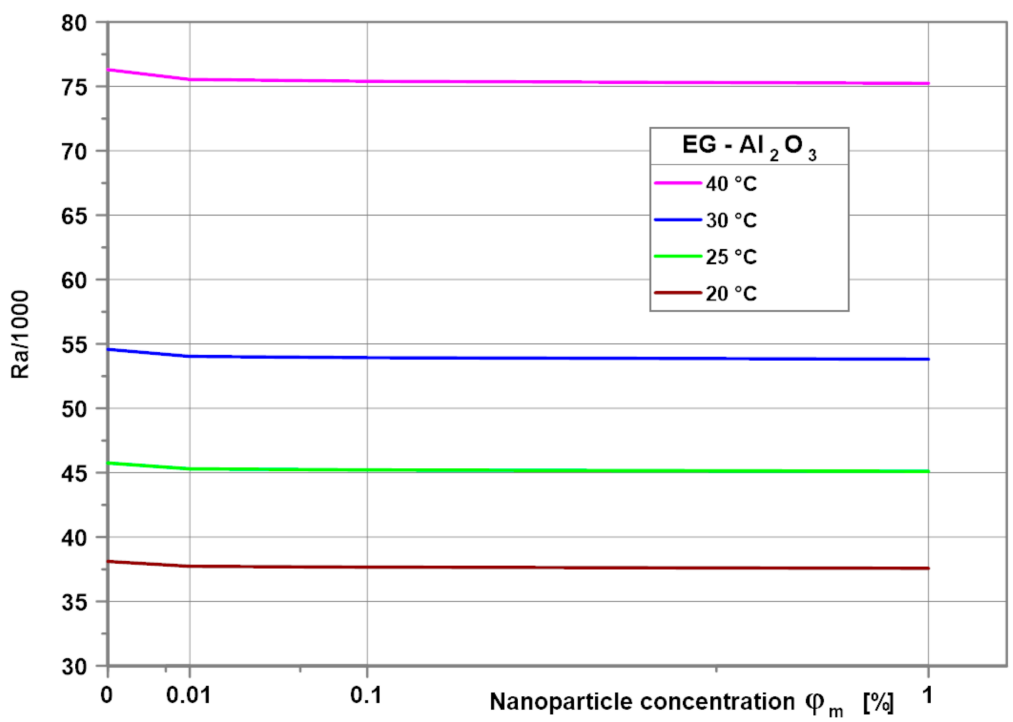

(b)

Figure 9. Variation of Ra number with temperature and nanoparticle concentration for water-based (a) and EG-based (b) nanofluids.

Figure 10 shows the variation of Nu number against nanoparticle mass concentration for water- $\mathrm{Al}_{2} \mathrm{O}_{3}$ nanofluids and two selected values of the Ra number, namely $10^{5}$ and $10^{6}$. Predictions from the Habibi et al. correlations (Equations (2) and (3)) were compared to the predictions from the correlation developed by the present authors (Equation (4)). Calculations were conducted for a constant $\operatorname{Pr}$ number of $\operatorname{Pr}=6.2$, as it was done by Habibi 
et al. [43]. As seen in Figure 10, the influence of nanoparticles on the Nu number for the tested mass concentration range $0.01 \% \leq \varphi_{m} \leq 1 \%$ was negligible for both tested Ra numbers.

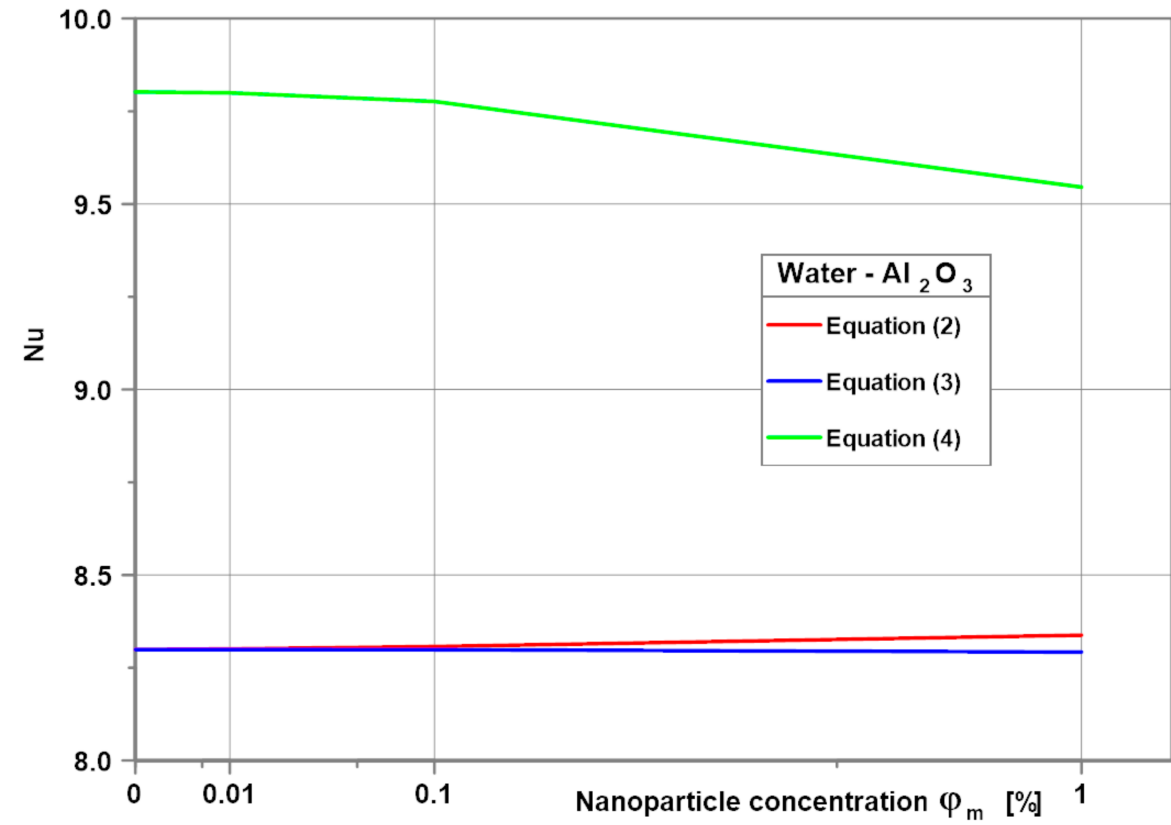

(a)

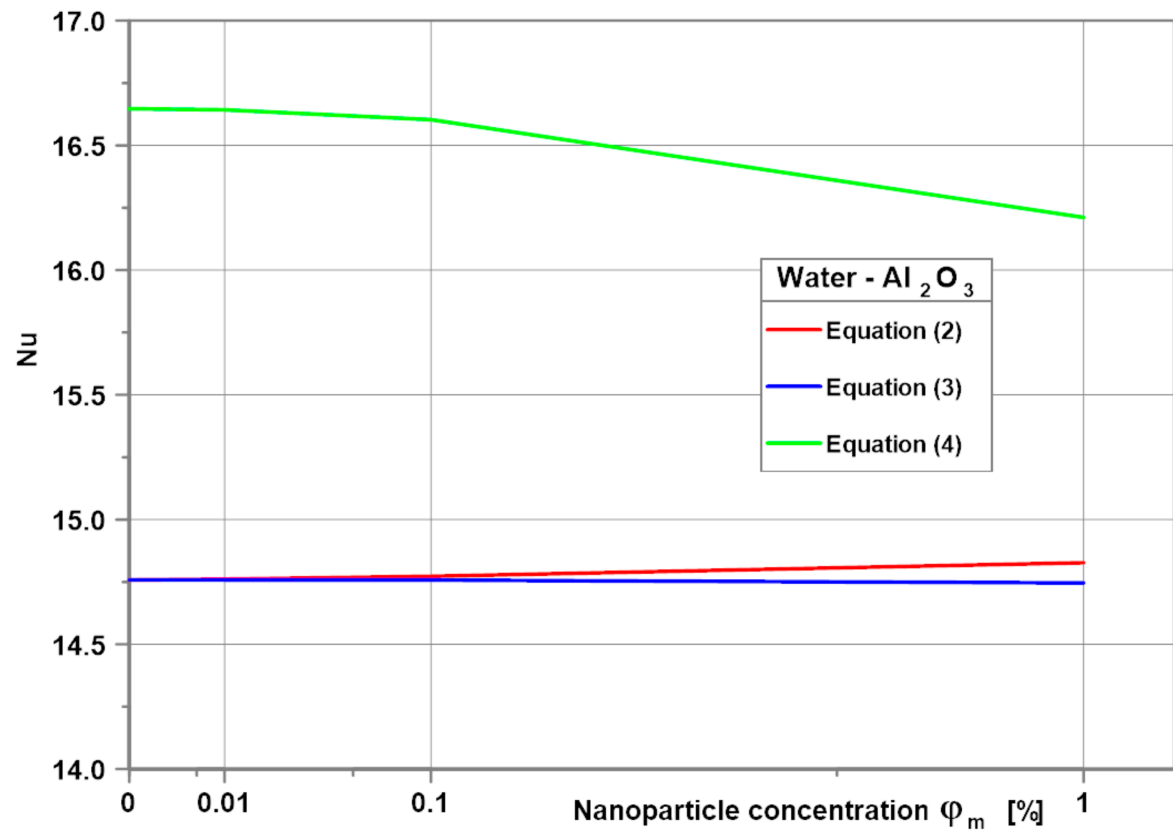

(b)

Figure 10. Variation of Nusselt number with nanoparticle mass concentration for water- $\mathrm{Al}_{2} \mathrm{O}_{3}$ nanofluids for $\mathrm{Ra}=10^{5}(\mathbf{a})$ and $\mathrm{Ra}=10^{6}(\mathbf{b})$.

Using Equation (4) and the experimental data presented in [36] $(\mathrm{D}=10 \mathrm{~mm}, \Delta \mathrm{T}=10 \mathrm{~K})$, the convective heat transfer coefficient was calculated for the water- $\mathrm{Al}_{2} \mathrm{O}_{3}$ and $\mathrm{EG}-\mathrm{Al}_{2} \mathrm{O}_{3}$ nanofluids. The base fluid heat transfer coefficient was obtained from the Churchill and Chu correlation (Equation (1)). Figure 11 shows the variation of the heat transfer coefficient for the tested nanofluids as a function of temperature. For water- $\mathrm{Al}_{2} \mathrm{O}_{3}$ nanofluids and temperature below $35^{\circ} \mathrm{C}$, the heat transfer coefficient was found to be higher than that 
of the base fluid (pure water). However, for temperatures higher than $35{ }^{\circ} \mathrm{C}$ and the maximum tested mass concentration $(1 \%)$, the advantage of nanofluids over the base fluid was diminished (Figure 11a). For EG- $\mathrm{Al}_{2} \mathrm{O}_{3}$ nanofluids and the whole temperature range, the heat transfer coefficient was found to be higher than that of the base fluid (pure EG). The highest heat transfer coefficient was observed for the minimum tested mass concentration, namely $0.01 \%$. The increase in the heat transfer coefficient in comparison to the predicted values from the Churchill and Chu correlation (Equation (1)) equalled 19\% for the lowest temperature tested $\left(20{ }^{\circ} \mathrm{C}\right)$, and decreased to $12.4 \%$ for the highest temperature tested $\left(40{ }^{\circ} \mathrm{C}\right)$ (Figure $\left.11 \mathrm{~b}\right)$.

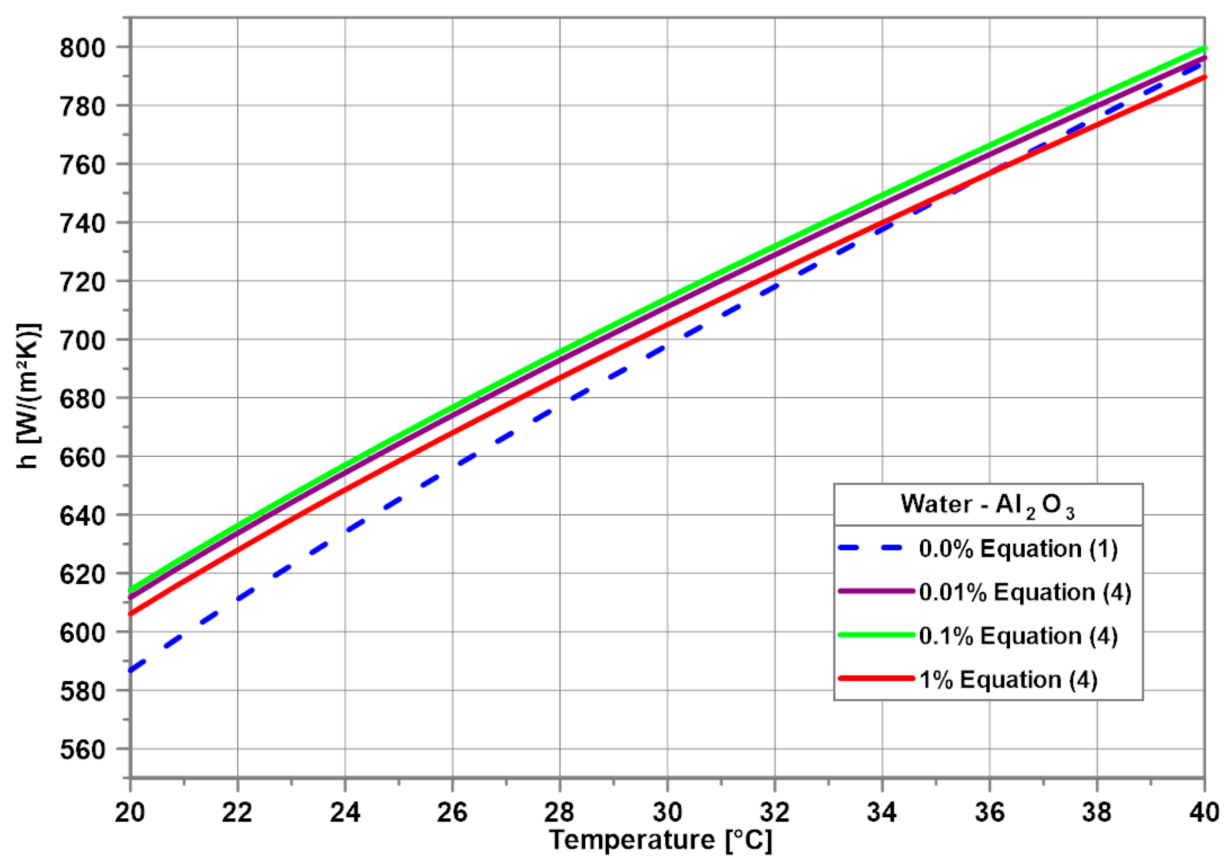

(a)

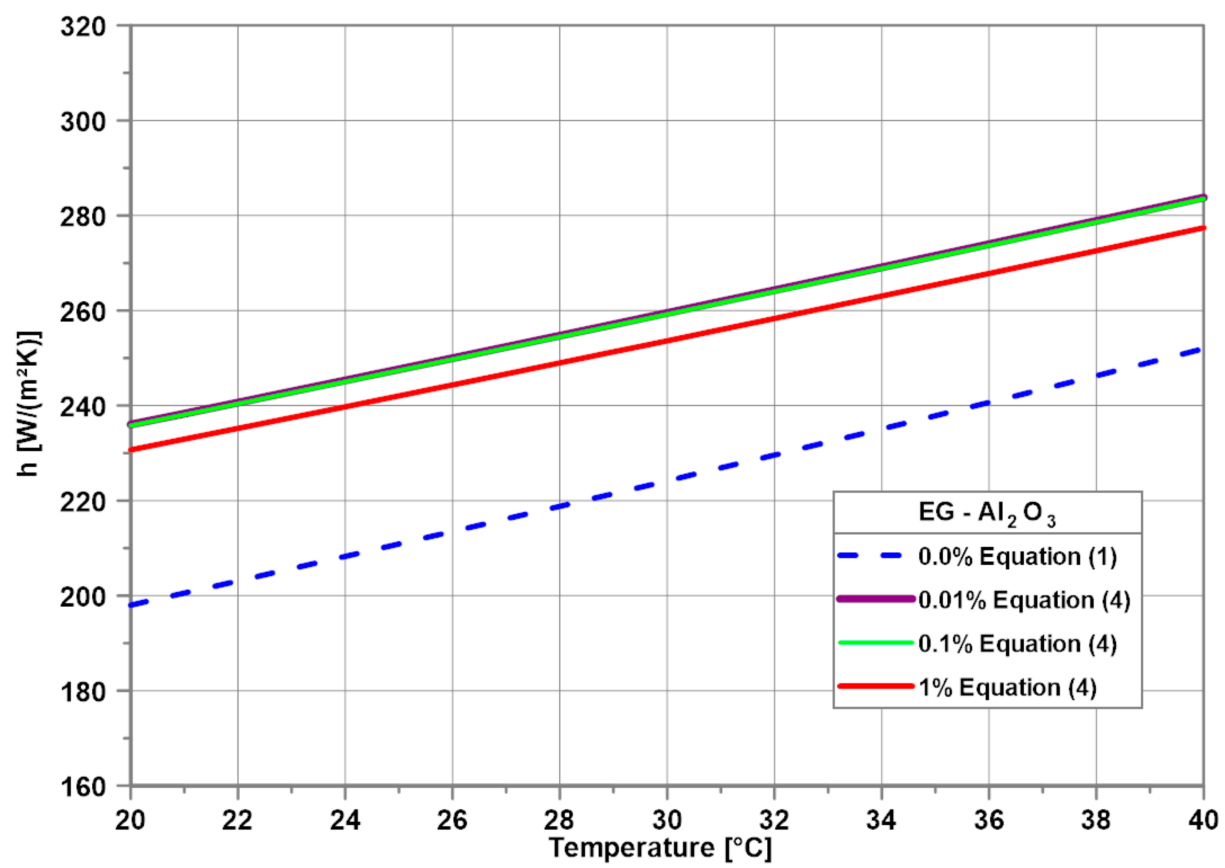

(b)

Figure 11. Impact of temperature and nanoparticle mass concentration on heat transfer coefficient for water-based (a) and EG-based (b) nanofluids. 


\section{Discussion and Conclusions}

The addition of $\mathrm{Al}_{2} \mathrm{O}_{3}$ nanoparticles to water and $\mathrm{EG}$ increases viscosity, thermal conductivity, and density. For example, the viscosity of the water- $\mathrm{Al}_{2} \mathrm{O}_{3}$ nanofluid of $1 \%$ mass concentration increased by $1 \%$ in comparison to the base fluid of water at the room temperature of $20^{\circ} \mathrm{C}$. Under the same conditions, the thermal conductivity of the same nanofluid increased by $3.4 \%$, the density by $0.7 \%$, the specific heat decreased by $0.1 \%$, and the thermal expansion coefficient was the same. Such inconsiderable changes of the thermophysical properties resulted from the very small nanoparticle concentrations tested, namely $0.01 \% \leq \varphi_{m} \leq 1 \%$ by weight. For room temperature, this mass nanoparticle concentration range corresponded to the volume nanoparticle concentration range $0.0028 \% \leq \varphi_{v} \leq 0.28 \%$.

Viscosity of the tested nanofluids increased with nanoparticle concentration. As a key factor in understanding the viscosity of nanofluids, the Brownian motion was indicated [55].

Thermal conductivity of nanofluids increased with nanoparticle concentration. As potential mechanisms of thermal conductivity enhancement, Brownian motion, thermophoresis, nanolayer, and clustering were mentioned [25].

Density of the tested nanofluids increased with nanoparticle concentration because the density of $\mathrm{Al}_{2} \mathrm{O}_{3}$ was above three times higher than pure water or EG.

The specific heat of the tested water-based nanofluids decreased with the nanoparticle concentration increase because the specific heat of $\mathrm{Al}_{2} \mathrm{O}_{3}$ was lower than the specific heat of pure water. The specific heat of the tested EG-based nanofluids is independent on $\mathrm{Al}_{2} \mathrm{O}_{3}$ nanoparticle concentration. Equation (16) was based on the assumption of thermal equilibrium between solid nanoparticles and the liquid phase. According to [44], these two phases are not in thermal equilibrium. Probably in the case of EG-based nanofluids, a more accurate correlation for specific heat is needed.

The influence of nanoparticle concentration on the thermal expansion coefficient was negligible because the thermal expansion coefficient of $\mathrm{Al}_{2} \mathrm{O}_{3}$ was at least two orders of magnitude lower than pure water or EG.

The Pr number of nanofluids decreased as the nanoparticle mass concentration increased (e.g., for the water- $\mathrm{Al}_{2} \mathrm{O}_{3}$ nanofluid of $1 \%$ concentration the decrease is $2.8 \%$ ), and decreased with an increase in temperature.

The Ra number slightly decreased with an increase in nanoparticle mass concentration and distinctly increased with temperature. As an example, for the water- $\mathrm{Al}_{2} \mathrm{O}_{3}$ nanofluid at $20{ }^{\circ} \mathrm{C}$, the Ra number decreased from $1.30 \times 10^{5}$ for $0.01 \%$ to $1.26 \times 10^{5}$ for $1 \%$ nanoparticle concentration, and at $40{ }^{\circ} \mathrm{C}$, the Ra number decreased from $3.32 \times 10^{5}$ for $0.01 \%$ to $3.23 \times 10^{5}$ for $1 \%$ nanoparticle concentration.

The convective heat transfer coefficient of nanofluids increased with an increase in temperature and concentration and was significantly higher than that of the base fluids. As an example, for a $1 \% \mathrm{EG}-\mathrm{Al}_{2} \mathrm{O}_{3}$ nanofluid, the convective heat transfer coefficient could increase by $16.5 \%$ compared to the base fluid at room temperature.

Author Contributions: Conceptualization, J.T.C.; methodology, J.T.C. and S.S.; software, S.S.; validation, J.T.C. and S.S.; formal analysis, J.T.C.; investigation, D.S.; data curation, S.S.; writing-original draft preparation, J.T.C.; writing - review and editing, J.T.C. and S.S.; funding acquisition, S.S. All authors have read and agreed to the published version of the manuscript.

Funding: This research received no external funding.

Institutional Review Board Statement: Not applicable.

Informed Consent Statement: Not applicable.

Data Availability Statement: Not applicable.

Acknowledgments: The authors thank Albrecht Eicke (City University of Applied Sciences Bremen) for kind cooperation during figure preparation.

Conflicts of Interest: The authors declare no conflict of interest. 


\section{Nomenclature}

$\begin{array}{lll}a & \text { Thermal diffusivity } & \left(\mathrm{m}^{2} / \mathrm{s}\right) \\ c_{p} & \text { Specific heat } & (\mathrm{J} /(\mathrm{kg} \mathrm{K})) \\ D & \text { Diameter } & (\mathrm{m}) \\ g & \text { Gravitational acceleration } & \left(\mathrm{m} / \mathrm{s}^{2}\right) \\ \mathrm{h} & \text { Heat transfer coefficient } & \left(\mathrm{W} /\left(\mathrm{m}^{2} \mathrm{~K}\right)\right) \\ k & \text { Thermal conductivity } & (\mathrm{W} /(\mathrm{m} \mathrm{K})) \\ N u=\frac{h D}{k} & \text { Nusselt number } & (-) \\ P r=\frac{v}{a}=\frac{\mu c_{p}}{k} & \text { Prandtl number } & (-) \\ R a=\frac{g \beta\left(T_{w}-T_{f}\right) D_{o}^{3}}{v a} & \text { Rayleigh number } & (-) \\ T & \text { Temperature } & (\mathrm{K}) \\ \Delta T & \text { Temperature difference } & (\mathrm{K}) \\ \mathrm{Greek} \mathrm{symbols} & & \\ \beta & \text { Thermal expansion coefficient } & (1 / \mathrm{K}) \\ \mu & \text { Dynamic viscosity } & (\mathrm{Pa} \mathrm{s}) \\ v & \text { Kinematic viscosity } & \left(\mathrm{m}^{2} / \mathrm{s}\right) \\ \varphi & \text { Nanoparticle concentration } & (-) \\ \rho & \text { Density } & \left(\mathrm{kg} / \mathrm{m}^{3}\right) \\ \text { Subscripts } & & \\ b f & \text { Base fluid } & \\ m & \text { Mass } & \\ \text { nf } & \text { Nanofluid } & \\ \text { o } & \text { Outside } & \\ p & \text { Particle } & \\ v & \text { Volume } & \\ \text { Abbreviations } & & \\ \text { DWCNT } & \text { Double-walled carbon nanotubes } \\ \text { MWCNT } & \text { Multi-walled carbon nanotubes } & \\ & & \end{array}$

\section{References}

1. Huminic, G.; Huminic, A. Application of nanofluids in heat exchangers: A review. Renew. Sustain. Energy Rev. 2012, 16, 5625-5638. [CrossRef]

2. Taylor, R.; Coulombe, S.; Otanicar, T.; Phelan, P.; Gunawan, A.; Lv, W.; Rosengarten, G.; Prasher, R.; Tyagi, H. Small particles, big impacts: A review of the diverse applications of nanofluids. J. Appl. Phys. 2013, 113, 011301. [CrossRef]

3. Sajid, M.U.; Ali, H.M. Recent advances in application of nanofluids in heat transfer devices: A critical review. Renew. Sustain. Energy Rev. 2019, 103, 556-592. [CrossRef]

4. Mahian, O.; Kolsi, L.; Amani, M.; Estellé, P.; Ahmadi, G.; Kleinstreuer, C.; Marshall, J.S.; Taylor, R.A.; Abu-Nada, E.; Rashidi, S.; et al. Recent advances in modeling and simulation of nanofluid flows-Part II: Applications. Phys. Rep. 2019, 791, 1-59. [CrossRef]

5. Kakaç, S.; Pramuanjaroenkij, A. Analysis of Convective Heat Transfer Enhancement by Nanofluids: Single-Phase and Two-Phase Treatments. J. Eng. Phys. Thermophys. 2016, 89, 758-793. [CrossRef]

6. Boertz, H.; Baars, A.; Cieśliński, J.T.; Smoleń, S. Numerical study of turbulent flow and heat transfer of nanofluids in pipes. Heat Transf. Eng. 2018, 39, 241-251. [CrossRef]

7. Javed, S.; Ali, H.M.; Babar, H.; Khan, M.S.; Janjua, M.M.; Bashir, M.A. Internal convective heat transfer of nanofluids in different flow regimes: A comprehensive review. Phys. A Stat. Mech. Appl. 2020, 538, 122783. [CrossRef]

8. Khanafer, K.; Vafai, K.; Lightstone, M. Buoyancy-driven heat transfer enhancement in a two-dimensional enclosure utilizing nanofluids. Int. J. Heat Mass Transf. 2003, 46, 3639-3653. [CrossRef]

9. Putra, N.; Roetzel, W.; Das, S.K. Natural convection of nanofluids. Heat Mass Transf. 2003, 39, 775-784. [CrossRef]

10. Wen, D.; Ding, Y. Formulation of nanofluids for natural convective heat transfer applications. Int. J. Heat Fluid Flow 2005, 26, 855-864. [CrossRef]

11. Polidori, G.; Fohanno, S.; Nguyen, C. A note on heat transfer modelling of Newtonian nanofluids in laminar free convection. Int. J. Therm. Sci. 2007, 46, 739-744. [CrossRef]

12. Ho, C.J.; Liu, W.; Chang, Y.; Lin, C. Natural convection heat transfer of alumina-water nanofluid in vertical square enclosures: An experimental study. Int. J. Therm. Sci. 2010, 49, 1345-1353. [CrossRef]

13. Li, C.H.; Peterson, G.P. Experimental studies of natural convection heat transfer of $\mathrm{Al}_{2} \mathrm{O}_{3} /$ DI water nanoparticle suspensions (Nanofluids). Adv. Mech. Eng. 2010, 2, 1-10. [CrossRef] 
14. Mahrood, M.R.K.; Etemad, S.G.; Bagheri, R. Free convection heat transfer of non Newtonian nanofluids under constant heat flux condition. Int. Commun. Heat Mass Transf. 2011, 38, 1449-1454. [CrossRef]

15. Cieśliński, J.T.; Krygier, K. Free convection of water- $\mathrm{Al}_{2} \mathrm{O}_{3}$ nanofluid from horizontal porous coated tube. Key Eng. Mater. 2013, 597, 15-20. [CrossRef]

16. Garbadeen, I.; Sharifpur, M.; Slabber, J.; Meyer, J. Experimental study on natural convection of MWCNT-water nanofluids in a square enclosure. Int. Commun. Heat Mass Transf. 2017, 88, 1-8. [CrossRef]

17. Rahimi, A.; Kasaeipoor, A.; Malekshah, E.H.; Kolsi, L. Experimental and numerical study on heat transfer performance of three-dimensional natural convection in an enclosure filled with DWCNTs-water nanofluid. Powder Technol. 2017, 322, 340-352. [CrossRef]

18. Minea, A.A.; Lorenzini, G. A numerical study on ZnO based nanofluids behavior on natural convection. Int. J. Heat Mass Transf. 2017, 114, 286-296. [CrossRef]

19. Reddy, P.S.; Chamkha, A.J. Heat and mass transfer characteristics of nanofluid over horizontal circular cylinder. Ain Shams Eng. J. 2018, 9, 707-716. [CrossRef]

20. Guestal, M.; Kadja, M.; Hoang, M.T. Study of heat transfer by natural convection of nanofluids in a partially heated cylindrical enclosure. Case Stud. Therm. Eng. 2018, 11, 135-144. [CrossRef]

21. Sawicka, D.; Baars, A.; Cieśliński, J.T.; Smoleń, S. Numerical simulation of natural convection of glycol- $\mathrm{Al}_{2} \mathrm{O}_{3}$ nanofluids from a horizontal cylinder. Heat Transf. Eng. 2019, 42, 328-336. [CrossRef]

22. Fand, R.; Morris, E.; Lum, M. Natural convection heat transfer from horizontal cylinders to air, water and silicone oils for rayleigh numbers between $3 \times 102$ and $2 \times 107$. Int. J. Heat Mass Transf. 1977, 20, 1173-1184. [CrossRef]

23. Khanafer, K.; Vafai, K. A critical synthesis of thermophysical characteristics of nanofluids. Nanotechnol. Energy 2017, 54, 279-332.

24. Rashmi, W.; Khalid, M.; Ong, S.S.; Saidur, R. Preparation, thermo-physical properties and heat transfer enhancement of nanofluids. Mater. Res. Express 2014, 1, 1-49. [CrossRef]

25. Angayarkanni, S.; Philip, J. Review on thermal properties of nanofluids: Recent developments. Adv. Colloid Interface Sci. 2015, 225, 146-176. [CrossRef] [PubMed]

26. Shahrul, I.; Mahbubul, I.; Khaleduzzaman, S.; Saidur, R.; Sabri, M. A comparative review on the specific heat of nanofluids for energy perspective. Renew. Sustain. Energy Rev. 2014, 38, 88-98. [CrossRef]

27. Hentschke, R. On the specific heat capacity enhancement in nanofluids. Nanoscale Res. Lett. 2016, 11, 1-11. [CrossRef] [PubMed]

28. Riazi, H.; Murphy, T.; Webber, G.; Atkin, R.; Tehrani, S.S.M.; Taylor, R.A. Specific heat control of nanofluids: A critical review. Int. J. Therm. Sci. 2016, 107, 25-38. [CrossRef]

29. Patil, M.S.; Seo, J.-H.; Kang, S.-J.; Lee, M.-Y. Review on synthesis, thermo-physical property, and heat transfer mechanism of nanofluids. Energies 2016, 9, 840. [CrossRef]

30. Kleinstreuer, C.; Feng, Y. Experimental and theoretical studies of nanofluid thermal conductivity enhancement: A review. Nanoscale Res. Lett. 2011, 6, 1-13.

31. Mishra, P.C.; Nayak, S.K.; Mukherjee, S. Thermal conductivity of nanofluids-An extensive literature review. Int. J. Eng. Res. Technol. 2013, 2, 1-12.

32. Mukherjee, S.; Mishra, P.C.; Parashar, S.K.S.; Chaudhuri, P. Role of temperature on thermal conductivity of nanofluids: A brief literature review. Heat Mass Transf. 2016, 52, 2575-2585. [CrossRef]

33. Yiamsawas, T.; Mahian, O.; Dalkilic, A.S.; Kaewnai, S.; Wongwises, S. Experimental studies on the viscosity of $\mathrm{TiO}_{2}$ and $\mathrm{Al}_{2} \mathrm{O}_{3}$ nanoparticles suspended in a mixture of ethylene glycol and water for high temperature applications. Appl. Energy 2013, 111, 40-45. [CrossRef]

34. Esfe, M.H.; Saedodin, S. An experimental investigation and new correlation of viscosity of ZnO-EG nanofluid at various temperatures and different solid volume fractions. Exp. Therm. Fluid Sci. 2014, 55, 1-5. [CrossRef]

35. Murshed, S.S.; Estellé, P. A state of the art review on viscosity of nanofluids. Renew. Sustain. Energy Rev. 2017, 76, 1134-1152. [CrossRef]

36. Sawicka, D.; Cieśliński, J.T.; Smolen, S. Experimental investigation of free convection heat transfer from horizontal cylinder to nanofluids. Energies 2021, 14, 2909. [CrossRef]

37. Churchill, S.W.; Chu, H.H. Correlating equations for laminar and turbulent free convection from a horizontal cylinder. Int. J. Heat Mass Transf. 1975, 18, 1049-1053. [CrossRef]

38. Pak, B.C.; Cho, Y.I. Hydrodynamic and heat transfer study of dispersed fluids with submicron metallic oxide particles. Exp. Heat Transf. 1998, 11, 151-170. [CrossRef]

39. Xuan, Y.; Li, Q. Investigation on convective heat transfer and flow features of nanofluids. J. Heat Transf. 2003, 125, 151-155. [CrossRef]

40. Maïga, S.E.B.; Palm, S.J.; Nguyen, C.T.; Roy, G.; Galanis, N. Heat transfer enhancement by using nanofluids in forced convection flows. Int. J. Heat Fluid Flow 2005, 26, 530-546. [CrossRef]

41. Vajjha, R.S.; Das, D.K.; Ray, D.R. Development of new correlations for the Nusselt number and the friction factor under turbulent flow of nanofluids in flat tubes. Int. J. Heat Mass Transf. 2015, 80, 353-367. [CrossRef]

42. Abouali, O.; Ahmadi, G. Computer simulations of natural convection of single phase nanofluids in simple enclosures: A critical review. Appl. Therm. Eng. 2012, 36, 1-13. [CrossRef] 
43. Habibi, M.R.; Amini, M.; Arefmanesh, A.; Ghasemikafrudi, E. Effects of viscosity variations on buoyancy-driven flow from a horizontal circular cylinder immersed in $\mathrm{Al}_{2} \mathrm{O}_{3}$-water nanofluid. Iran. J. Chem. Eng. 2018, 38, 213-232.

44. Vajjha, R.S.; Das, D.K. Specific heat measurement of three nanofluids and development of new correlations. J. Heat Transf. 2009, 131, 071601. [CrossRef]

45. Buongiorno, J.; Venerus, D.C.; Prabhat, N.; McKrell, T.J.; Townsend, J.; Christianson, R.J.; Tolmachev, Y.; Keblinski, P.; Hu, L.-W.; Alvarado, J.L.; et al. A benchmark study on the thermal conductivity of nanofluids. J. Appl. Phys. 2009, 106, 094312. [CrossRef]

46. Meyer, J.P.; Adio, S.A.; Sharifpur, M.; Nwosu, P.N. The Viscosity of Nanofluids: A review of the theoretical, empirical, and numerical models. Heat Transf. Eng. 2016, 37, 387-421. [CrossRef]

47. Bashirnezhad, K.; Bazri, S.; Safaei, M.R.; Goodarzi, M.; Dahari, M.; Mahian, O.; Dalkılıça, A.S.; Wongwises, S. Viscosity of nanofluids: A review of recent experimental studies. Int. Commun. Heat Mass Transf. 2016, 73, 114-123. [CrossRef]

48. Corcione, M. Empirical correlating equations for predicting the effective thermal conductivity and dynamic viscosity of nanofluids. Energy Convers. Manag. 2011, 52, 789-793. [CrossRef]

49. Sawicka, D.; Cieśliński, J.T.; Smoleń, S. A comparison of empirical correlations of viscosity and thermal conductivity of waterethylene glycol-Al2O3 Nanofluids. Nanomaterials 2020, 10, 1487. [CrossRef]

50. Aybar, H.Ş.; Sharifpur, M.; Azizian, M.R.; Mehrabi, M.; Meyer, J.P. A Review of Thermal Conductivity Models for Nanofluids. Heat Transf. Eng. 2015, 36, 1085-1110. [CrossRef]

51. American Society of Heating; Refrigerating and Air-Conditioning Engineers. ASHRAE Handbook-Fundamentals; ASHRAE: Atlanta, GA, USA, 2005.

52. Hwang, K.S.; Lee, J.-H.; Jang, S.P. Buoyancy-driven heat transfer of water-based $\mathrm{Al}_{2} \mathrm{O}_{3}$ nanofluids in a rectangular cavity. Int. J. Heat Mass Transf. 2007, 50, 4003-4010. [CrossRef]

53. Ho, C.; Chen, M.; Li, Z. Numerical simulation of natural convection of nanofluid in a square enclosure: Effects due to uncertainties of viscosity and thermal conductivity. Int. J. Heat Mass Transf. 2008, 51, 4506-4516. [CrossRef]

54. Bergman, T.L.; Lavine, A.S.; Incropera, F.P.; Dewitt, D.P. Fundamentals of Heat and Mass Transfer; John Wiley and Sons: Hoboken, NJ, USA, 2011.

55. Kole, M.; Dey, T.K. Thermal conductivity and viscosity of Al2O3nanofluid based on car engine coolant. J. Phys. D Appl. Phys. 2010, 43, 1-10. [CrossRef] 